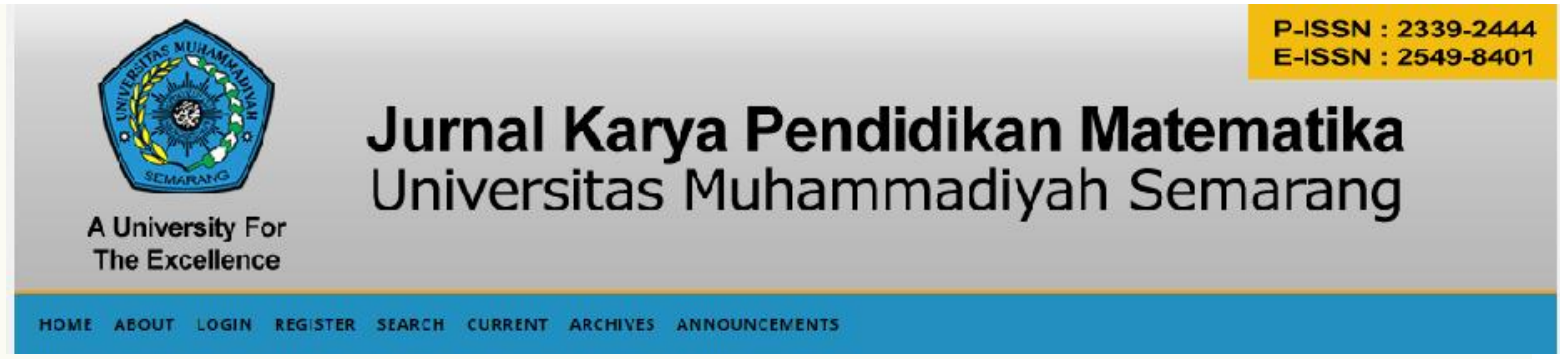

\title{
PENINGKATAN HASIL BELAJAR MATEMATIKA MELALUI MODEL PROBLEM BASED LEARNING BERBANTUAN MEDIA PUZZLE SISWA KELAS IV SD
}

\author{
Ferna Setiana $^{1)}$, Theresia Sri Rahayu ${ }^{2)}$, Wasitohadi ${ }^{3)}$ \\ 292015066@student.uksw.edu, th.rahayu@gmail.com, wasito.hadi@uksw.edu
}

Fakultas Keguruan dan Ilmu Pendidikan

Universitas Kristen Satya Wacana Salatiga

\begin{tabular}{ll}
\hline \multicolumn{2}{l}{ Article history } \\
\hline Submission & $: 26 / 2 / 2019$ \\
Revised & $:-$ \\
Accepted & $: 4 / 5 / 2019$
\end{tabular}

Keyword: Problem Based Learning Model, media puzzle, and Mathematics learning outcomes.

Kata kunci: Model

Problem Based Learning, media puzzle, dan hasil belajar Matematika.

\begin{abstract}
Pendahuluan
Pada Permendikbud Tahun 2016

No.22 mengenai standar proses dinyatakan tentang proses pembelajaran dalam setiap satuan pendidikan diselenggarakan secara menyenangkan, interaktif, menantang, inspiratif, dan memotivasi siswa dalam belajar. Agar siswa mampu berperan aktif di sekolah dasar, dengan memperkenalkan berbagai pengetahuan dan keterampilan. Salah satu keterampilan yang diutamakan adalah keterampilan berhitung pada pembelajaran khususnya pada pembelajaran matematika.
\end{abstract}

\begin{abstract}
This study aims to improve student mathematics learning outcomes Class Action Research in two cycles. In this study, the data collection is used, namely documentation, observation, and written tests. The data analysis technique used is quantitative and qualitative descriptive outcomes seen in the pre-cycle of 34 students there were 15 results of the first cycle increased to 24 students or $70 \%$ with average value of 68, then in cycle II it increased again to 30 students or $89 \%$ with an average value of 80 .
\end{abstract}


meningkatkan kemampuan berpikir siswa yang nantinya dapat meningkatkan hasil belajar siswa.Namun pada proses pembelajaran Matematika anak masih mengalami kesulitan dalam memahami materi pembelajaran, sehingga hasil belajar siswa masih rendah. Cristina dan kristin (2016: 223) hasil belajar merupakan perubahan perilaku siswa setelah mengikuti pelajaran yang dibuat guru melalui model pembelajaran yang dipilih dan digunakan dalam suatu pembelajaran. Sedangkan menurut Yupita (2013: 5) menyatakan bahwa hasil belajar adalah kemampuan yang diperoleh peserta didik saat dan setelah melakukan proses pembelajaran mencakup nilai ranah afektif, kognitif maupun psikomotor dari proses pembelajaran yang dilaksanakan dalam waktu tertentu. Kemampuan-kemampuan yang dimiliki oleh siswa setelah belajar yang mencakup ranah afektif, dan psikomotor akibat suasana atau lingkungan belajar yang diciptakan oleh guru melalui model pembelajaran yang digunakan dalam suatu pembelajaran, sehingga saat pembelajaran guru harus mampu memilih model pembelajaran yang tepat saat pelajaran.

Namun pelaksanaan pembelajaran Matematika siswa kelas IV SD N Kecandran 01 Salatiga dilaksanakan dengan menjelaskan materi kemudian memberikan soal atau tugas pada siswa. Dalam menjelaskan materi kadang-kadang menggunakan media papan tulis dan belum menggunakan model yang bervariasi. Siswa terlihat kurang berpartisipasi dalam kegiatan pembelajaran. Kesesuaian media pembelajaran yang menunjang pencapaian tujuan pembelajaran belum didesain atau disiapkan lebih awal. Akibatnya hasil belajar siswa belum mencapai nilai KKM (kriteria Ketuntasan Minimal) yaitu 70. Untuk mengatasi hal tersebut perlu menerapkan model pembelajaran yang berbasis masalah agar siswa dapat ikut berpartisipasi serta lebih aktif dalam kegiatan pembelajaran.

Model pembelajaran berbasis masalah salah satunya model Problem Based Learning (PBL). Menurut Ngalimun (2014: 89) pembelajaran berdasarkan masalahProblem Based Learning merupakan salah satu model pembelajaran inovatif yang dapat memberikan kondisi belajar aktif kepada siswa. Menurut Rusman (2014:241) pembelajaran berbasis masalah salah satu pembelajaran yang digunakan untuk merangsang berpikir tingkat tinggi siswa dalam situasi yang berorientasi pada masalah dunia, nyata termasuk di dalamnya belajar bagaiamana belajar.

Langkah-langkah berbasis masalah atau Problem Based Learning (PBL) ada 5 tahap menurut Suprijono (2014: 74) terdiri dari tahap 1. Memberikan orientasi tentang permasalahannya kepada siswa, tahap 2 . Mengorganisasikan siswa untuk meneliti. Guru membentuk siswa untuk mendefinisikan dan mengorganisasikan tugas belajar yang berhubungan sengan masalah, tahap 3 . Membimbing penyelidikan individual maupun kelompok, tahap 4. Mengembangkan dan menyajikan hasil karya dan tahap 5 . Menganalisis dan mengevaluasi proses pemecahan masalah. Guru membantu siswa untuk melakukan refleksi atau evaluasi terhadap penyelidikan mereka dan prosesproses yang mereka gunakan. Hasil evaluasi tersebut dapat digunakan untuk melihat hasil belajar siswa.

Tidak hanya menggunakan model pembelajaran yang berbasis masalah agar siswa lebih berpartisipasi dan aktif sehingga hasil belajar meningkat, namun dalam pembelajaran perlu ditunjang dengan menggunakan media agar pembelajaran lebih menarik. Salah satunya dengan menggunakan media puzzle. Menurut Hairuddin (2014: 210) media puzzle merupakan permainan anakanak. Anak-anak bertugas menyusun potongan-potongan gambar yang terpisah. Potongan gambar tersebut memiliki berbagai bentuk seperti jajar genjang, trapesium, persegi, persegi panjang, dan sebagainya. Disusun sedemikian rupa agar membentuk satu gambar yang utuh. Media puzzle yang digunakan pada model Problem Based Learning (PBL) sebagai alat perantara penyajian masalah untuk diselesaikan dengan cara menyusun agar membentuk pola bangun datar yang diharapkan dan siswa lebih tertarik pada pembelajaran yang dapat mempengaruhi hasil belajar lebih meningkat.

Penelitian ini bertujuan untuk meningkatkan hasil belajar Matematika melalui model Problem Based Learning (PBL) berbantuan media puzzle berguna untuk meningkatkan kualitas pembelajaran serta dapat memperkaya ilmu pengetahuan pendidikan khususnya tentang pemilihan 
model pembelajaran yang tepat dan efektif dalam meningkatkan hasil belajar siswa dan dapat dijadikan sebagai referensi agar pembelajaran lebih bervariasi.

\section{Metode Penelitian}

\section{Jenis Penelitian}

Penelitian dilakukan adalah Penelitian Tindakan Kelas (PTK) dilaksanakan untuk mengetahui hasil belajar siswa pada mata pelajaran Matematika. Jenis penelitian ini menggunakan model Kemmis dan Mac Tanggart dengan 3 tahapan yaitu Planning (Perencanaan), Acting (Pelaksanaan Tindakan) dan Observasing (Pengamatan) serta Reflecting (Refleksi).

\section{Waktu dan Tempat Penelitian}

Penelitian ini dilaksanakan pada bulan Januari 2019-Februari 2019 di SD N Kecandran 01 Salatiga pada semester II tahun pelajaran 2018/2019 yang terletak di Jl. Kyai Nurwahid Karang padang, Kelurahan Kecandran, Kecamatan Sidomukti, Kota Salatiga.

\section{Subjek Penelitian}

Populasi dari penelitian ini adalah siswa kelas IV SD N Kecandran 01 Salatiga Kelurahan Kecandran Kecamatan Sidomukti, Kota Salatiga yang berjumlah 34 siswa terdiri dari 20 siswa laki-laki dan 14 siswa perempuan.

\section{Teknik Pengumpulan Data}

Tabel 1. Analisis Komparatif Ketuntasan Hasil Belajar Matematika Kelas IV SD N Kecandran 01 Salatiga Semester II Tahun Pelajaran 2018/2019 Pra Siklus, Siklus I, dan Siklus II

\begin{tabular}{|c|c|c|c|c|c|c|c|c|}
\hline \multirow[t]{2}{*}{ No. } & \multirow{2}{*}{$\begin{array}{c}\text { Ketuntasan } \\
\text { Belajar }\end{array}$} & \multirow[t]{2}{*}{ Nilai } & \multicolumn{2}{|c|}{ Pra Siklus } & \multicolumn{2}{|c|}{ Siklus I } & \multicolumn{2}{|c|}{ Siklus II } \\
\hline & & & $\begin{array}{c}\text { Jumlah } \\
\text { Siswa }\end{array}$ & $(\%)$ & $\begin{array}{c}\text { Jumlah } \\
\text { Siswa }\end{array}$ & $(\%)$ & $\begin{array}{c}\text { Jumlah } \\
\text { Siswa }\end{array}$ & $(\%)$ \\
\hline 1. & Tuntas & $\geq 70$ & 15 & 41 & 24 & 70 & 30 & 89 \\
\hline 2. & Tidak Tuntas & $<70$ & 19 & 59 & 10 & 30 & 4 & 11 \\
\hline \multicolumn{3}{|c|}{ Jumlah } & 34 & 100 & 34 & 100 & 34 & 100 \\
\hline \multicolumn{3}{|c|}{ Nilai Rata-rata } & \multicolumn{2}{|c|}{61} & \multicolumn{2}{|c|}{68} & \multicolumn{2}{|c|}{80} \\
\hline
\end{tabular}

Berdasarkan tabel 1 pada kegiatan pra siklus dari 34 siswa jumlah siswa yang tuntas hanya 15 siswa atau $41 \%$, sedangkan yang tidak tuntas 19 siswa atau $59 \%$ dengan nilai rata-rata 61. Pada siklus I siswa yang tuntas meningkat yaitu 24 siswa atau 70\%, sedangkan yang tidak tuntas 10 siswa atau $30 \%$ dengan nilai rata-rata 68. Pada siklus II siswa mengalami peningkatan ketuntasan yaitu 30 siswa atau $89 \%$, sedangkan yang belum tuntas hanya 4
Dalam penelitian ini teknik pengumpulan data yang digunakan yaitu dokumentasi, observasi, dan tes tertulis. Dokumentasi dalam penelitian ini dipilih untuk mengetahui jumlah siswa dan kondisi sekolah. Observasi dipilih untuk mengetahui data tentang tingkah laku dan kegiatan siswa serta guru saat proses pembelajaran sedang berlangsung. Tes tertulis dalam bentuk pilihan ganda digunakan untuk mendapatkan data mengenai hasil belajar siswa.

\section{Teknik Analisis Data}

Teknik analisis data yang digunakan yaitu teknik deskriptif kuantitatif dan kualitatif. Data kuantitatif adalah data yang diperoleh dari hasil tes berupa soal pilihan ganda, data disajikan dalam bentuk angka. Sedangkan data yang berasal dari hasil lembar siswa dan guru berupa penjelasan atau keterangan adalah data kualitatif. Untuk menjamin kelayakan soal pilihan ganda dalam penelitian dengan uji validitas dan uji reabilitas.

\section{Hasil Penelitian dan Pembahasan}

Hasil penelitian yang dilakukan pra siklus, siklus I, dan siklus II di kelas IV SD N Kecandran 01 Salatiga menunjukan adanya peningkatkan hasil belajar Problem Based Learning (PBL) berbantuan media puzzle. Hal tersebut dapat dilihat dari hasil belajar siswa pada tabel 1 berikut ini. 


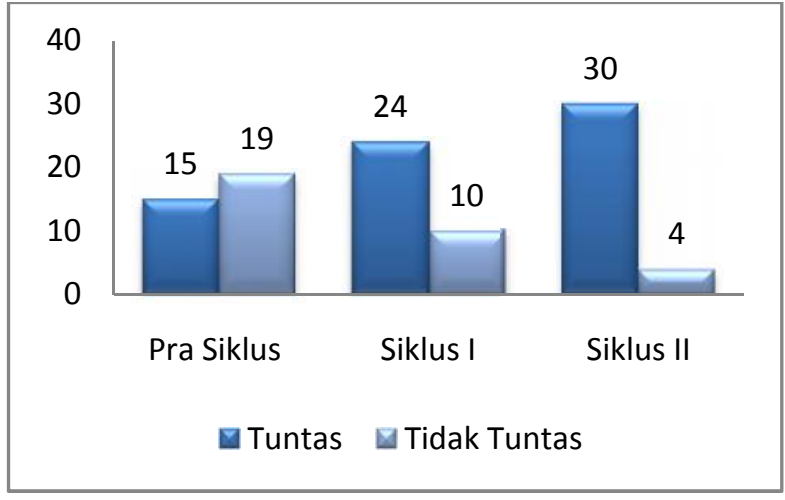

Gambar 1. Perbandingan Frekuensi Hasil Belajar Matematika Siswa Pra Siklus, Siklus I, dan Siklus II Kelas IV SD N Kecandran 01 Salatiga Semester II Tahun Pelajaran 2018/2019

\section{Pembahasan}

Berdasarkan hasil analisis data penelitian yang telah dilaksanakan terjadi peningkatan hasil belajar siswa dari pra siklus hingga siklus II pada siswa kelas IV SD N Kecandran 01 Salatiga pada mata pelajaran Matematika. Dari hasil observasi pra siklus 34 siswa terdapat 19 siswa atau $59 \%$ yang belum tuntas dan 15 siswa atau $41 \%$ yang telah mencapai batas ketuntasan minimal (KKM) yaitu $\geq 70$. Sesuai dengan permasalahan yang ada, peneliti melaksanakan tindakan menggunakan model Problem Based Learning (PBL) berbantuan media puzzle. Penelitian yang dilakukan dalam dua siklus dengan dasar permasalahan yang ada pada kondisi awal. Penelitian ini dibantu oleh guru kelas sebagai observer, Dengan model pembelajaran ini peneliti dapat menyelesaikan permasalahan yang ada. Peneliti menerapkan model Problem Based Learning (PBL) berbantuan media puzzle di pertemuan pertama dan pertemuan kedua disetiap siklusnya sesuai dengan rencana tindakan yang telah dirancang. Langkah-langkah model Problem Based Learning (PBL) yaitu memberikan orientasi siswa pada masalah dengan memberikan siswa puzzle dengan bentuk persegi, persegi panjang, dan segitiga, mengorganisasi siswa untuk belajar, membimbing pengalaman individu atau kelompok dengan mengarahkan agar menyusun puzzle yang nantinya membentuk bangun datar persegi, persegi panjang, dan segitiga, kemudian mendiskusikan soal terkait bangun tersebut, lalu dikembangkan dan menyajikan hasil diskusi tersebut sebagai bahan refleksi atau evaluasi.

Setelah dilakukan tindakan kelas dengan menggunakan model Problem Based Learning (PBL) berbantuan media puzzle pada siklus I dengan kompetensi dasar menjelaskan dan menentukan keliling dan luas persegi, persegi panjang, dan segitiga serta hubungan pangkat dua dengan akar pangkat dua meningkat menjadi 24 atau $70 \%$ siswa yang tuntas dan 10 atau $30 \%$ yang belum tuntas, namun dalam siklus Ibelum memenuhi indikator kinerja yang ditentukan dalam penelitian, maka dilanjut penelitian tindakan kelas dengan siklus II dengan kompetensi dasar, dari hasil siklus II diperoleh data siswa yang tuntas meningkat signifikan dari 34 siswa yang tuntas 30 atau $89 \%$ sedangkan yang tidak tuntas hanya 4 atau $11 \%$ siswa. Dalam proses pembelajaran dengan menggunakan model Problem Based Learning (PBL) membuktikan kelebihan yang telah dikemukakan oleh Rahmadani N (Warsono dan Hariyanto, 2013: 152) adalah siswa terbiasa menghadapi masalah dan merasa tertantang untuk menyelesaikan masalah yang terkait dengan pembelajaran dalam kelas maupun dunia nyata, dengan terbiasa berdiskusi dengan teman dapat meningkatkan keakraban antara guru dengan siswa.

Namun pada siklus II masih terdapat 4 siswa atau $11 \%$ yang belum tuntas. Hasil belajar dipengaruhi oleh beberapa faktor yaitu faktor internal dan faktor eksternal. Kemudian peneliti melakukan wawancara dengan guru kelas dan pengamatan saat pembelajaran berlangsung dapat disimpulkan bahwa 4 siswa yang tidak tuntas ini disebabkan oleh faktor internalnya karena memang tingkat kecerdasan atau kemampuan yang rendah dalam menyerap pelajaran dibandingkan dengan siswa lainnya atau dibawah rata-rata terutama dalam mata pelajaran matematika. Selain itu sikap yang ditunjukan oleh siswa ini sering tidak memperhatikan guru saat mengajar dan lebih asyik bermain sendiri atau menjahili teman. Sedangkanfaktoreksternal yang mempengaruhi yaitu keluarga atau orang tua yang kurang memperhatikan belajar anak saat dirumah, orang tua bekerja berangkat pagi pulang larut malam tanpa memperhatikan anak daan menyuruh untuk belajar sehingga siswa tersebut dirumah hanya bermain-main. Untuk 
mengatasi permasalahan tersebut, yang dilakukan guru adalah memberikan treatment yang bersifat individu, misalnya dengan memberikan remidial, pengayaan maupun jam tambahan belajar setelah pulang sekolah.

Hasil penelitian yang membuktikan keberhasilan model Problem Based Learning (PBL) berbantuan media puzzle ini memperkuat dan melengkapi penelitian yang terdahulu. Penelitian yang sejalan dengan penelitian yang dilakukan oleh Nurkhotimah, Siti (2017) yang berjudul "Penerapan Model Problem Based Learning (PBL) dengan Media Konkret untuk Meningkatkan Hasil Belajar Matematika Tentang Operasi Hitung Pecahan Pada Siswa Kelas V SD N 1 Kuwayuhan Tahun Ajaran 2016/2017" hasil penelitian tersebut terbukti bahwa model Problem Based Learning (PBL) dapat meningkatkan hasil belajar matematika pada siklis I ketuntasan belajar $82,15 \%$ kemudian dilakukan tindakan lanjut siklus II ketuntasan meningkat menjadi $89,28 \%$, dan pada siklus III sebesar 96,55\%. Sama dengan hasil penelitian yang dilakukan oleh Suryo, Ariz (2016) dengan judul "Penggunaan Metode Problem Based Learning (PBL) Berbantuan Media Audio Visual untuk Meningkatkan Hasil Belajar Matematika Siswa Sekolah Dasar" hasil penelitian menunjukan adanya peningkatan hasil belajar. Dari 21 siswa pada siklus I 9 siswa atau $42,9 \%$ yang tuntas, pada siklus II meningkat menjadi 16 siswa atau 76,19 sedangkan pada siklus III 19 siswa atau 90,47\%. Penelitian yang dilakuakan Hadi, Fida Rahmantika dengan judul "Penerapan Pembelajaran Problem Based Learning (PBL) untuk Meningkatkan Hasil Belajar Matematika Siswa Kelas IV Sekolah Dasar" menunjukan bahwa terjadi peningkatan hasil belajar siswa. Pada pra tindakan nilai rata-rata kelas 71,31 siswa yang belum tuntas $47,4 \%$, pada siklus II rata-rata menjadi 75,78 siswa yang belum tuntas ada 36,8\% sedangkan pada siklus III rata-rata kelas menjadi 82,63 dan semua siswa tuntas. Selain itu penelitian Vitasari, Rizka (2016) dengan menerapkan model Problem Based Learning dapat meningkatkan hasil belajar siswa terbukti pada siklus I nilai ratarata sebesar 62,8 atau $54,2 \%$ dan siklus II dengan nilai rata-rata sebesar 88,1 atau $85,4 \%$. Jadi dari siklus I hingga siklus II mengalami peningkatan 25,3 atau $31,2 \%$.
Hasil penelitian ini juga sesuai dengan pengertian hasil belajar adalah kegiatan belajar mengajar yang dapat menimbulkan tingkah laku pada siswa. Hasil belajar mencakup antara lain aspek kognitif, afektif, dan psikomotor, namun dalam hal ini lebih mengutamakan pada kemampuan kognitif yang dilakukan guru untuk mengukur beberapa pengetahuan siswa setelah melakukan pembelajaran Halimah dan Sumardjono (2017: 270-278). Setelah dilakukan penelitian tindakan kelas, peningkatan hasil belajar siswa mengalami peningkatan dari kemampuan pengetahuan siswa menjadi lebih baik.

Penelitian ini memiliki keunggulan dibandingkan dengan penelitian yang dilakukan sebelumnya karena penelitian ini dalam penerapan model Problem Based Learning I (PBL) menggunakan media puzzle dalam mata pelajaran matematika kurikulum 2013 di Sekolah Dasar. Dalam mengukur pengetahuan menggunakan soal tes berbentuk pilihan ganda dan hasilnya diperkuat dengan pengamatan maupun wawancara yang dilakukan dengan guru.

\section{Simpulan dan Saran \\ Simpulan}

Berdasarkan hasil penelitian tindakan kelas yang dilakukan di SD N Kecandran 01 Salatiga beserta pembahasan, maka dapat simpulan dari penelitian sebagai berikut:

a. Peningkatan hasil belajar Matematika melalui model Problem Based Learning (PBL) berbantuan media puzzle siswa kelas IV SD N Kecandran 01 Salatiga Semester II Tahun Pelajaran 2018/2019 dibukitkan oleh meningkatnya ketuntasan hasil belajar siswa. Pada pra siklus dari 34 siswa terdapat 15 siswa atau $41 \%$ yang tuntas dengan nilai rata-rata 61. Kemudian hasil dari siklus I meningkat menjadi 24 siswa atau $70 \%$ dengan nilai rata-rata 68 , kemudian pada siklus II meningkat kembali menjadi 30 siswa atau $89 \%$ dengan nilai rata-rata 80 .

b. Dengan menerapkan model Problem Based Learning (PBL) berbantuan media puzzle dapat meningkatkan hasil belajar Matematika pada siswa kelas IV SD N Kecandran 01 Salatiga Semester II Tahun Pelajaran 2018/2019.

\section{Saran}

12

http://jurnal.unimus.ac.id/index.php/JPMat/index 
Berdasarkan hasil penelitian yang dilakukan pada siswa kelas IV SD $\mathrm{N}$ Kecandran 01 Salatiga, maka dapat mengemukakan saran sebagai berikut.

1. Bagi Sekolah

Diharapkan dapat mendukung kreatifitas guru dan siswa dalam rangka memperbaiki dan meningkatkan mutu lulusan agar dapat bersaing.

2. Bagi Siswa

Diharapkan agar dapat bekerja sama dengan baik dan dapat berperan aktif dalam mencapai tujuan pembelajaran agar berguna dalam kehidupan sehari-hari dalam mata pelajaran matematika maupun berbagai mata pelajaran.

3. Bagi Guru

Diharapkan dapat menggunakan model Problem Based Learning (PBL) berbantuan media puzzle dalam melakukan kegiatan belajar mengajar agar dapat meningkatkan hasil belajar siswa.

4. Bagi Peneliti

Disarankan agar mengkaji lebih banyak sumber maupun referensi yang terkait dengan model Problem Based Learning (PBL) berbantuan media puzzle agar hasil yang didapatkan dapat lebih baik dan lengkap.

\section{Daftar Pustaka}

Christina, L.V dan Firosalia Kristin. (2016). Efektivitas Model Pembelajaran Tipe Group Investigation (GI) dan Cooperative Integrated Reading And Composition (CIRC) Dalam Meningkatkan Kreativitas Berpikir Kritis Dan Hasil Belajar IPS Siswa Kelas 4. Scholaria: Jurnal Pendidikan dan Kebudayaan. 6 (3), 217-230

Hadi, Fida Rahmantika. (2016). Penerapan Pembelajaran Problem Based Learning (PBL) untuk Meningkatkan Hasil Belajar Matematika Siswa Kelas IV Sekolah Dasar.Pofesi Pendidikan Dasar. 3 (2). 84-91

Halimah, N dan Sumardjono. (2017). Perbedaan Pengaruh Model Student Teams Achievement Division (STAD) Dan Numbered Heads Together (NHT) Terhadap Hasil Belajar Matematika Siswa Kelas V SD. Scholaria: Jurnal Pendidikan dan Kebudayaan, 7 (3), 267 - 275
Hariuddin, Enni K. (2014). Membentuk Karakter Anak dari Rumah. Jakarta: PT Elex Media.

Ngalimun. (2014). Strategi dan Model Pembelajaran. Yogyakarta: Aswaja Pressindo.

Nurkhotimah, Siti. (2017). Penerapan Model Problem Based Learning (PBL) Dengan Media Konkret untuk Meningkatkan Hasil Belajar Matematika Tentang Operasi Hitung Pecahan Pada Siswa Kelas V SDN 1 Kuwayuhan Tahun Ajaran 2016/2017. KALAM CENDEKIA. 5 (3.1), 256-260

Permendikbud. (2016). Permendikbud Th. 2016 No. 022 - Lampiran. Jakarta: Menteri Pendidikan dan Kebudayaan.

Rahmadani N, Normala dan Indri Anugraheni. (2017).

PENINGKATAN AKTIVITAS BELAJAR MATEMATIKA MELALUI PENDEKATAN PROBLEM BASED LEARNING BAGI SISWA KELAS 4 SD. Scholaria: Jurnal Penelitian dan Kebudayaan. 7 (3). 241-250

Rusman. (2012). Model-Model Pembelajaran Mengembangkan Profesionalisme Guru. Jakarta: PT. Rajagrafindo Persada.

Sugiyanto. (2010). Model-model Pembelajaran Inovatif (Cetakan Ke-2). Surakarta: Yuma Pressindo.

Suprijono, Agus. (2014). Cooperatif Learning. Yogyakarta: Pustaka Belajar.

Suryo, Ariz dan Slameto. (2016). Penggunaan Metode Problem Based Learning (PBL) Berbantuan Media Audio Visual untuk Meningkatkan Hasil Belajar Matematika Siswa Sekolah Dasar. Jurnal Pendidikan Dasar. 4 (2)

Susanto, Ahmad. (2013). Teori Belajar dan Pembelajaran di Sekolah Dasar. Jakarta: Kencana Prenata Media Group.

Vitasari, Rizka, Joharman dan Chrysti Suryandari. (2016). Peningkatan Keaktifan dan Hasil BelajarMatematika Melalui Model Problem Based Learning Siswa Kelas V SD Negeri 5 Kutosari. FKIP PGSD Universitas Sebelas Maret. 4 (3)

Yupita, I. A., \& S, W. T. (2013). Penerapan Model Discovery Learning untuk

http://jurnal.unimus.ac.id/index.php/JPMat/index 
Jurnal Karya Pendidikan Matematika Vol 6 No 12019 E ISSN : 2549 - 8401 P ISSN : 2339-2444

Meningkatkan Hasil Belajar IPS di Sekolah Dasar. JGPGSD, 5. 